\title{
NEUROBEHAVIORAL CONSEQUENCES OF CHRONIC LEAD INTOXICATION: EFFECTS OF VITAMIN E SUPPLEMENTATION
}

\author{
Received February 5, 2014
}

\begin{abstract}
We investigated the effects of vitamin E supplementation on neurobehavioral alterations induced by chronic ingestion of lead acetate in mice. The animals were divided into three main groups, group 1 (control) given with normal saline $(10 \mathrm{ml} / \mathrm{kg}$ ) and groups 2 and 3 given with $3000 \mathrm{mg} / \mathrm{kg}$ lead acetate alone and in combination with 13 IU of vitamin E, respectively, for a period of 90 days. Lead intoxication resulted in significant $(P<0.05)$ reduction of the number of head dips in the hole-board test and the time spent in the open arm of the elevated plus maze test, compared with the control. Intoxication also induced increased pain sensitivity, as shown by significant $(P<0.05)$ reduction in the tail flick latency and increase in the frequency of abdominal constrictions in the writhing test. The periods of immobility in both tail suspension and forced swimming tests in intoxicated animals were greater, as compared with the control. Co-administration of vitamin $\mathrm{E}$ with lead in group 3 significantly $(P<0.05)$ reversed all the mentioned shifts (increased the number of head dips and time spent in the maze open arm, increased the tail flick latency, decreased the frequency of writhings, and decreased the periods of immobility in the forced swimming and tail suspension tests). Thus, vitamin E treatment is capable of effectively attenuating the negative neurobehavioral consequences of lead intoxication.
\end{abstract}

Keywords: lead intoxication, vitamin E, neurobehavioral indices, anxiety, pain, depression.

\section{INTRODUCTION}

Heavy metals, in particular lead, are extensively used in industry, building, and everyday life; they represent important factors in contemporary contamination of the environment. Most heavy metals do not play known physiological roles in the organism, but their harmful effects are obvious.

Lead intoxication strongly influences negatively a variety of biological process in many organs and tissues; its effects on the nervous system are especially significant [1]. Although the use of lead in various spheres has at present been minimized, exposure to this factor still creates strong biological risks due to its stable presence in the environment.

Common sources of lead include some paints, contaminated dust, and drinking water [2]; ingestion, inhalation, and dermal contacts are common routes of exposure [3]. Children are more vulnerable to lead exposure due, in part, to a high rate of absorption

\footnotetext{
${ }^{1}$ Department of Physiology, College of Medicine, University of Ibadan, Ibadan, Nigeria.

Correspondence should be addressed to G. F. Ibironke

(e-mail: gibironk@yahoo.com).
}

after ingestion [4]; in this part of the population, lead intoxication induces irreversible learning and behavioral deficits. Thus, a search for ways of ameliorating the negative effects of chronic lead exposure is urgent.

Various food supplements were proposed for this purpose. Among them, there is $\beta$-tocopherol, a form of vitamin $\mathrm{E}$ characterized by very high antioxidant activity. Vitamin $\mathrm{E}$ is a fat-soluble vitamin found in significant amounts in vegetable oils, cereals, meat, poultry eggs, fruits, and some vegetables. This vitamin may exert some positive effects in diabetes [6]. A number of clinical trials and a smaller number of supplementation studies were carried out to investigate the effects of $\beta$-tocopherol in cardiovascular diseases, but with largely negative results [7]. Information on the effects of $\beta$-tocopherol in the case of lead toxicity is very scarce. We attempted to test the usefulness of vitamin E supplementation on neurobehavioral alterations in mice induced by experimental chronic lead intoxication.

\section{METHODS}

Animals. Male albino Swiss mice (20-30 g) were used in the study. The animals were housed and bred in the 
pre-clinical animal house of the College of Medicine, University of Ibadan, Nigeria. They were kept under standard vivarium conditions (room temperature and 12/12 h light-dark cycle), fed with standard mouse cubes (Ladokun Feeds, Nigeria), and provided with water ad libitum.

The animals were randomly divided into three groups with six mice in each. Within the exposure period (90 days), mice of group I (control) received perorally (p.o.) normal saline $(10 \mathrm{ml} / \mathrm{kg})$, group II received also p.o. $3000 \mathrm{mg} / \mathrm{kg}$ of lead acetate, and group III received a combination of $3000 \mathrm{mg} / \mathrm{kg}$ of lead acetate and 13 IU vitamin E. Lead acetate trihydrate (Oxford Laboratory, India) was dissolved in drinking water. Vitamin E was obtained from a local pharmaceutical outfit (Ibadan, Nigeria).

Hole Board Test. The standard test was carried out on a wooden board $(40 \times 40 \mathrm{~cm})$ with 16 evenly spaced holes, as previously described [8]. The number of head dips into holes within a 5-min-long observation period was counted.

Elevated Plus Maze Test. The standard version of the test was used. The time spent by an animal during the observation period in the open arm of the maze characterized the level of anxiety.

In all the above experiments, the arenas were cleaned after each test with $70 \%$ alcohol to eliminate olfactory bias.

Tail Withdrawal Test. A modification of the original tail flick test was used [10]. The animal was gently hand-held with a piece of towel, and a terminal 3 -cm-long segment of the tail was immersed in a water bath maintained at $52 \pm 0.2^{\circ} \mathrm{C}$. The time taken for the animal to flick its tail out of water was taken as the tail withdrawal latency.

Acetic Acid Writhing Test. The test was carried out as previously described [9]. Acetic acid (0.2 $\mathrm{ml}, 3 \%)$ was injected i.p. to induce the characteristic writhings. The number of the latter occurring between the 5th and 10 th min post injection was measured.

Tail Suspension Test. The tail suspension test (TST) was performed according to the method described earlier [11]. Mice were individually suspended 60 $\mathrm{cm}$ above the surface of a table with an adhesive tape placed $1 \mathrm{~cm}$ away from the tip of the tail. The immobility duration was recorded within the last $5 \mathrm{~min}$ during $6 \mathrm{~min}$ of observation. Mice were considered immobile only when they hung passively and were completely motionless.

Forced Swimming Test. A standard variant of this test was used. Mice were put into cold water $\left(10^{\circ} \mathrm{C}\right)$, and the period of immobility before attempts to swim was measured.

\section{RESULTS}

Effects of Lead Intoxication and Its Treatment With Vitamin $E$ on the Level of Anxiety. Chronic intoxication with lead (group 2) induced significant $(P<0.05)$ reductions in the frequency of head dips in the hole-board test and the duration of stay of the tested mice in the open arm of the elevated plus maze, as compared with the control group 1. In the former test, the difference from the control values (decrement) was about $47 \%$, while in the latter test it was about $24 \%$ (Fig. 1 A, B). When peroral introduction of lead acetate was combined with administration of vitamin E (group 3, lead + vitamin E), these negative effects were neutralized, and the respective indices (numbers of head dips and time spent for exploration of the open arm) even somewhat (insignificantly, $P>0.05$ ) exceeded the control data. At the same time, these values in group 3 significantly $(P<0.05)$ exceeded the respective values in group 2 (lead alone) (Fig. 1A, B).

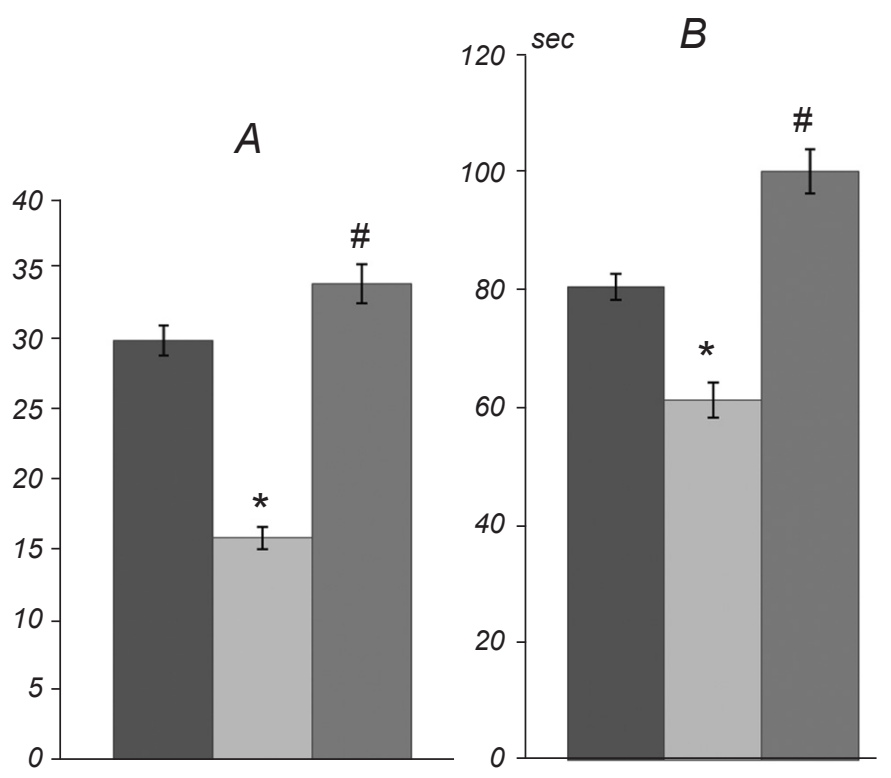

F i g. 1. Effects of lead and vitamin $E$ on the indices characterizing the anxiety level. A) Number of head dips in the hole-board test; B) time, sec, spent in the open arm of the elevated plus maze. Groups 1-3 are the control, treated with lead acetate alone, and treated with lead acetate + vitamin E, respectively. Means \pm s.e.m are shown, $n=6$ in each group. $* P<0.05$ compared with the control (group 1); ${ }^{\#} P<0.05$ compared with group 2 .

Р и с. 1. Впливи свинцю та вітаміну Е на показники, що характеризують рівень тривожності. 
Effects of lead intoxication and its treatment with vitamin $E$ on the results of the open field test. Chronic lead intoxication noticeably suppressed locomotion activities (mean number of crossed squares) in the above test; the respective index in group 2 was only $76 \%$ of that in the control group 1 . The treatment with vitamin E neutralized this negative shift, and locomotor activity in group 3 was even more intense than in the control (Fig. 2). Lead intoxication also significantly suppressed orientation/research activity of mice (number of stands) and grooming activity. The treatment with vitamin $\mathrm{E}$ in group 3 provided considerable correction effects on the respective indices.

Effects of lead intoxication and its treatment with vitamin $E$ on the pain sensitivity. Leadintoxicated mice demonstrated increased sensitivity to thermal pain stimulation in the tail-flick test. The mean latency of the tail-flick reaction in group 2 was equal to $47 \%$ of that in the control group $(P<0.05$, Fig. 3A). The sensitivity of animals with respect to chemically induced visceral pain in the writhing test was also significantly higher than that in the control; the increment in the mean number of writhings was about $31 \%(P<0.05$, Fig. 3B). Parallel treatment of intoxicated mice with vitamin E completely neutralized negative consequences of lead intoxication (in comparison of group 3 with group $2, P<0.05$ in both tests) and even provided rather intense analgesic effects, as compared with the control group 1 (Fig. 3A, B).

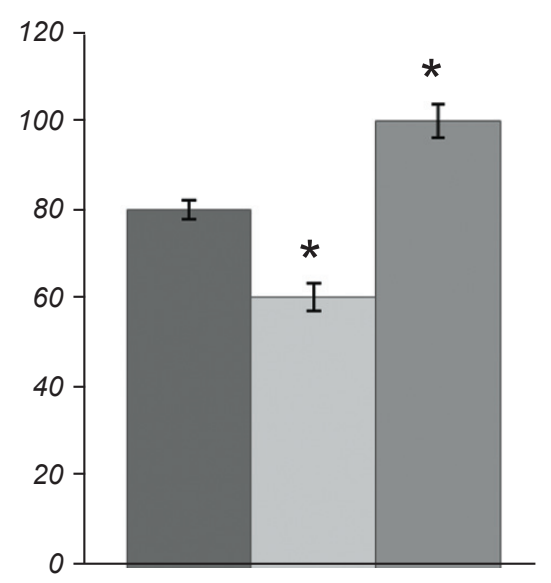

F i g. 2. Mean values of the locomotion activities observed in the open field test in the control and treated groups. Designations are the same as in Fig. 1.

Р и с. 2. Середні індекси локомоторної активності в тесті відкритого поля у мишей контрольної та експериментальної груп.
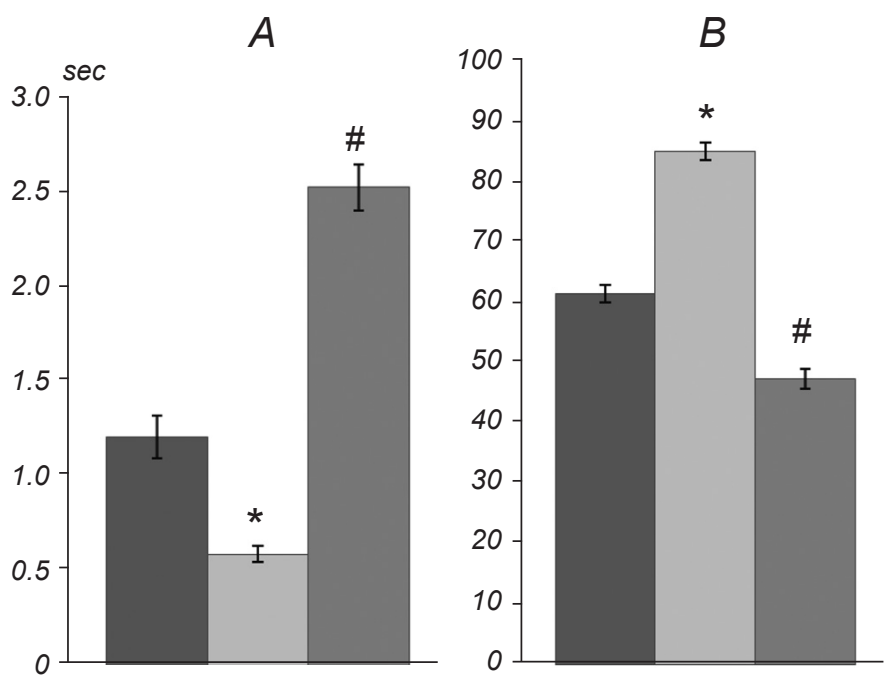

F i g. 3. Effects of lead and vitamin E on the sensitivity to pain. A) Tail flick latency, sec; B) number of writhings within the observation period. Designations are the same as in Figs. 1 and 2.

Р и с. 3. Впливи свинцю та вітаміну Е на чутливість до болю.
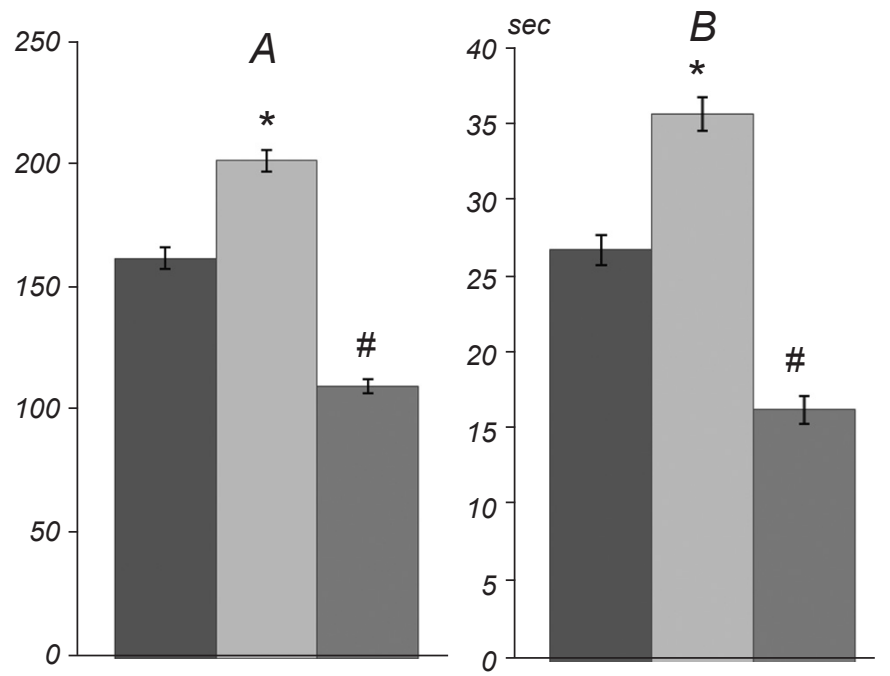

F i g. 4. Effects of lead and vitamin $\mathrm{E}$ on the indices characterizing the level of depression. A) Period of immobility, sec, in the tail suspension test, sec; B) that in the forced swimming test. Designations are the same as in Figs. 1-3.

P и с. 4. Впливи свинцю та вітаміну Е на показники, що характеризують рівень депресії.

Effects of lead intoxication and its treatment with vitamin $E$ on the depression-related indices. In group 2 (administration of lead acetate alone), the average period of immobility in the tail suspension test was $16 \%$ longer than that in the control group 1 $(P<0.05)$. The treatment of lead-intoxicated mice with vitamin E (group 3$)$ significantly $(P<0.05)$ decreased 
the respective time interval, as compared with that in group 2 (Fig. 4A). Nearly the same situation was observed in the force swimming test. The mean period of immobility in group- 2 mice exceeded by $32 \%$ the corresponding index in control mice (group 1). A quite comparable decrease in this index related to introduction of vitamin $\mathrm{E}$ was observed in group 3 compared with group 2 (Fig. 4B).

\section{DISCUSSION}

In our study, we examined the effects of chronic lead intoxication (peroral introduction) on a few neurobehavioral indices in mice and the effects of treatment with vitamin $\mathrm{E}$ on the respective alterations. The results obtained demonstrated a clear ability of vitamin $\mathrm{E}$ (in the doses tested) to reverse negative behavioral changes induced by chronic lead ingestion.

Lead intoxication resulted in a clear increase in the level of anxiety in tested animals. Manifestations of orientation/research activity (characterized by the number of muzzle dips in the openings of the holeboard plate and time spent in the open arm of the elevated plus maze) in lead-intoxicated mice were noticeably smaller than the respective values in the control. These shifts toward greater values of anxiety in group-2 mice were effectively neutralized by accompanying treatment with vitamin $\mathrm{E}$ in group 3 .

Ingestion of large amounts of lead also resulted in the development of noticeable hyperalgesia in experimental mice of group 2. This was demonstrated by an about twofold drop of the tail flick latency (thermally evoked somatic pain) and a noticeable increase in the intensity of writhings in the respective test (chemically induced visceral pain). These negative shifts were removed by the treatment with vitamin E, and even relative hypoalgesia was observed in group-3 mice in both above-mentioned tests.

Quite comparable results were obtained in the tail suspension and forced swimming tests. In both tests, the initial periods of immobility (which is usually interpreted as an index of the depression level) were in lead-intoxicated mice noticeably longer than those in the control. Again, these negative shifts could be effectively removed by the E vitamin treatment.
Thus, chronic lead intoxication provides clear anxiogenic and depressive effects and increases in the sensitivity to somatic and visceral pain. Coadministration of vitamin E effectively removed the negative effects of lead. The orientation/research activity of the intoxicated mice is intensified, locomotor activity in the open field test increased, and hyperalgesia in group- 2 mice is replaced by relative hypoalgesia in group-3 animals. In other words, vitamin $\mathrm{E}$ is a rather effective means for amelioration of negative behavioral effects of lead intoxication.

Antioxidants, in general, have been shown to inhibit apoptosis [2], a mechanism supposed to contribute to the development of lead neurotoxicity. Since vitamin $\mathrm{E}$ is a powerful antioxidant, this mechanism might in part be responsible for amelioration of the respective neurotoxic effect.

Oxidative damage was shown to be associated with the molecular mechanism of lead poisoning [12]. Lead is capable of easily penetrating the blood-brain barrier, thereby making the brain easily susceptible to free-radical damage and, hence, oxidative stress. Our data convincingly demonstrate that lead neurotoxicity is due, to a considerable extent, to the development of such stress because vitamin E, as a powerful antioxidant, effectively removes the respective negative neurobehavioral shifts. No doubt, other mechanisms of lead intoxication and effects counteracting this intoxication cannot be ruled out and should be examined in the future.

In conclusion, our study demonstrated that vitamin E, when co-administered with lead acetate, significantly reversed negative neurobehavioral alterations induced by chronic lead ingestion. This vitamin, therefore, might be of clinical importance in the management of lead poisoning.

All experimental protocols were in agreement with the internationally accepted ethical norms and with the guidelines of the Ethics Committe of the College of Medicine, University of Ibadan, Nigeria.

The authors of this study, G. F. Ibironke and S. T. Adu, confirm that the research and publication of the results were not associated with any conflicts regarding commercial or financial relations, relations with organizations and/or individuals who may have been related to the study, and interrelations of coauthors of the article. 
Г. Ф. Ібіронке, С. Т. Аду ${ }^{l}$

\section{НЕЙРОПОВЕДІНКОВІ НАСЛІДКИ ХРОНІЧНОГО ОТРУСННЯ СВИНЦЕМ: КОРЕКЦІЙНІ ВПЛИВИ BITAMIHY E}

${ }^{1}$ Медичний коледж Ібаданського університету, Ібадан (Нігерія).

P е 3 ю м е

Ми досліджували зміни нейроповедінкових показників у мишей, викликані хронічним пероральним уведенням ацетату свинцю, та корекцію цих змін за допомогою вітаміну Е. Тварини були поділені на три групи: контрольну групу 1 , що отримувала фізіологічний розчин (10 мл/кг), та групи 2 і 3, котрим протягом 90 діб уводили 3000 мг/кг ацетату свинцю ізольовано або в комбінації з 13 М.О. вітаміну Е відповідно. Свинцева інтоксикація зумовлювала істотне $(P<0.05)$ зменшення кількості зазирань в отвори під час проходження тесту «отвори в дошці» та часу, проведеного у відкритих рукавах «підвищеного» лабіринту. Інтоксикація також призводила до підвищення чутливості до болю, про що свідчили істотні скорочення латентного періоду відсмикування хвоста та збільшення кількості «корчів», індукованих уведенням оцтової кислоти, у відповідних тестах. Періоди нерухомості у тестах підвішування за хвіст та примусового плавання в інтоксикованих тварин були довшими, ніж у контролі. Паралельне уведення вітаміну Е тваринам групи 3 істотно $(P<0.05)$ нейтралізувало вказані негативні зрушення. Ставали більшими число зазирань в отвори та час, проведений у відкритих рукавах лабіринту; латентний період відсмикування хвоста подовжувався, а число «корчів» зменшувалося; періоди імобілізації у згаданих вище тестах скорочувалися. Отже, вітамін Е, будучи потужним антиоксидантом, ефективно згладжує негативні нейроповедінкові наслідки свинцевої інтоксикації.

\section{REFERENCES}

1. P. J. Landrigan and A. C. Toold, "Lead poisoning," West Afr. J. Med., 161, 153-159 (1994).

2. A. Garza, R. Vega, and E. Soto, "Cellular mechanism of lead neurotoxicity," Med. Sci. Monit., 12, No. 3, 57-65 (2006).

3. M. Pizzol, M. Thomsen, and M. S. Anderson, "Long term human exposure to lead from different media and intake pathways," Sci. Total Environ., 5478-5488 (2010).

4. K. Koller, T. Brown, A. Spurgeon, and L. Lemy, "Recent development in low level lead exposure and intellectual impairment in children," Environ. Health Perspect., 112, No. 9, 987-994 (2004).

5. D. C. Bellinger, "Very low lead exposure and children with neurodevelopment," Current. Opin. Pediat., 20, 172-177 (2008).

6. G. David, M. Romano, and A. Mezzetti, "Increased level of soluble P-selectin in hypercholesterolemic patients," Circulation, 97, 953-957 (1998).

7. S. Yusuf, "Clinical, public health and research implication of the heart outcome prevention evaluation (HOPE) study," Eur. Heart J., 22, 103-104 (2001).

8. R. M. G. Perez, J. A. L. Perez, L. M. D. Garcia, and H. M. Sossa, "Neuropharmacological activity of Solanumnigrum fruit," $J$. Ethnopharmacol., 62, 43-48 (1998).

9. A. Ajayi and O. E. Ukponmwan, "Evidence of angiotensin II and endogenous opioid and modulation of novelty induced rearing in the rats," Afr. J. Med. Sci., 23, 287-290 (1993)

10. W. L. D'Armour and D. L Smith, "A method for determining loss of pain sensation," J. Pharmacol. Exp. Ther., 72, 74-79 (1941).

11. L. Steru, R. Chermat, B. Thiery, and P. Simon, "The tail suspension test: a new method for screening antidepressants in mice," Psychopharmacology, 85, 367-370 (1985).

12. M. Ahmed and M. K. Siddiqqui, "Low level lead exposure and oxidative stress: Current opinions," Clin. Chim. Acta, 383, Nos. 1/2, 57-64 2007). 